\title{
A Perspective on U.S. International Trade
}

\author{
William Poole
}

I am very pleased to be back in Louisville again, to meet tomorrow with the board of the Louisville branch of the Federal Reserve Bank of St. Louis and today to discuss trade issues with the Louisville Society of Financial Analysts. Trade is an important issue for the United States and for the entire world. My purpose is to review the fundamentals of the argument for free trade in the hope that returning to basics will be helpful to public understanding of trade issues.

A well-known joke says that you could lay all the world's economists end to end and they still wouldn't reach a conclusion. And Harry Truman's famous plea was for a one-armed economist. In fact, there is no issue on which economists are more closely in agreement than the fundamental case for free trade. Economists end to end see eye to eye on this issue, and the two-armed economist does not go through the usual dance "on the one hand, on the other hand" when discussing the fundamental case for free trade. There are special cases and temporary exceptions that modify the case for free trade, but they do not challenge the basic argument.

Despite this consensus among economists, substantial public opposition to reducing trade barriers exists. In fact, opposition can be found at both the left and right ends-and the middle-of the political spectrum.

In my remarks today, I will address three questions. First, why do economists support free trade policies? Second, what are the reasons for public opposition? Third, what can be done to narrow the gap between economists and those opposed to free trade?

Before proceeding, I want to emphasize that the views I express here are mine and do not necessarily reflect official positions of the Federal Reserve System. I thank my colleagues at the Federal Reserve Bank of St. Louis for their comments-especially

Cletus Coughlin, vice president in the Research Division, who provided special assistance. However, I retain full responsibility for errors.

\section{THE OPINIONS OF ECONOMISTS AND THE GENERAL PUBLIC ON FREE TRADE}

A 1990 survey of economists employed in the United States found that more than 90 percent generally agreed with the proposition that the use of tariffs and import quotas reduced the average standard of living. ${ }^{1}$ These results are more than a decade old; however, few economists would disagree with the following statement that appeared in 2001: "The consensus among mainstream economists on the desirability of free trade remains almost universal." 2

On the other hand, the general public is much more reluctant to reduce trade barriers than economists are. Well-publicized protests against meetings to discuss the reduction of trade barriers have become common. The concern about free trade policies is not limited to the protestors. In a 1998 survey, only 32 percent of the general public was in favor of eliminating tariffs and other import restrictions to achieve lower prices when the cost would be that certain jobs in import-competing industries would likely be eliminated. ${ }^{3}$ Meanwhile, 49 percent were more sympathetic to the argument that tariffs are necessary to protect jobs.

\section{WHY ECONOMISTS SUPPORT FREE TRADE POLICIES}

Underlying the consensus among economists is the judgment that nations are better off with free

\footnotetext{
1 See Alston, Kearl, and Vaughan (1992).

2 See Mayda and Rodrik (2001, p. 1).

3 See Reilly (1999).
}

William Poole is the president of the Federal Reserve Bank of St. Louis. This article was adapted from a speech of the same title presented at the Louisville Society of Financial Analysts, Louisville, Kentucky, November 19, 2003. The author thanks colleagues at the Federal Reserve Bank of St. Louis for comments: Cletus Coughlin, vice president and deputy director of research, provided special assistance. The views expressed are the author's and do not necessarily reflect official positions of the Federal Reserve System.

Federal Reserve Bank of St. Louis Review, March/April 2004, 86(2), pp. 1-7.

(C) 2004, The Federal Reserve Bank of St. Louis. 
trade than with policies restricting trade. Before I begin discussing the analytics of international trade, let's begin by thinking about our own behavior. Most of us have jobs. With the income from our jobs, we buy numerous goods and services-food, clothing, fuel, houses, entertainment, and so on. Our economic behavior reflects the fact that we live in a highly interdependent world in which jobs are specialized. A typical household buys goods and services produced not only in its home state but also throughout the United States and the rest of the world. Indeed, each of us directly consumes only a tiny proportion of our production - the most important exception is household services, such as cleaning, cooking, and yard care. Would our lives be better if each of us individually grew all of our food, made all our clothes, pumped and refined all our oil, built our own houses and made movies? Obviously, the answer is no. Even the early settlers on the American frontier relied on others to make many of their tools, for example. Pure self-sufficiency is a recipe for a Stone Age standard of living.

Broadening the arena for trade just a little would help just a little. Would the residents of Kentucky be better off if they traded only with others in Kentucky and had no economic relationships with the rest of the United States? Once again, the answer is no. By specializing in certain activities, regions as well as individuals are able to maximize the value of work effort. By producing most goods and services for sale to others, we trade our output for the goods and services that we are not especially adept at producing.

The wisdom of specialization and exchange that holds for individual and interregional trade holds for international trade as well. Nearly 200 years ago, the economist David Ricardo demonstrated the gains from trade. To explain the principle of comparative advantage he used the example of England and Portugal trading cloth and port wine. The trade made both countries better off. His work was a generalization of Adam Smith's great insights concerning the gains from exchange.

Ricardo's theory of comparative advantage showed that nations, similar to individuals, gain from trade. Assuming that relative prices, such as the price of an apple relative to the price of a shirt, differ across two countries, then both countries can gain from trading with each other. An important point is that, even if the average worker in one country is more productive in producing each and every good than the average worker in the other country, gains from trade are possible. The gains from trade depend on comparative and not absolute advantage.

I believe it was Paul Samuelson, the first Nobel Laureate in the United States, who gave this example: Suppose an economist is a brilliant theorist and the best typist in the university. Should the economist type her own papers? Clearly, the economist will be more productive if she hires a secretary to do the typing; she, the economist, has a comparative advantage in developing economic theory and he, the secretary, has a comparative advantage in typing.

The same principle of comparative advantage holds for a country. If Portugal can produce both port wine and cloth with fewer hours of labor input per unit of output than can England, it will still pay Portugal to produce wine and trade with England for cloth, assuming that England is comparatively more efficient in producing cloth than wine. The proposition generalizes to many goods and many countries. As long as resources move into those activities in which the country is most advantaged or least disadvantaged, then all trading partners can be better off by trading some of the output that they produce at relatively low cost for some of the output that they produce at relatively high cost.

So far my discussion has focused on what economists term the "static gains" from trade. These gains arise from the reallocation of existing productive resources and the subsequent international trade. Free trade might also generate dynamic gains by stimulating economic growth. Economic theory suggests a number of routes by which free trade stimulates economic growth by increasing either productive resources or technological change. In practice, these increases are often triggered by the spur of competition when countries liberalize trade. There are many success stories of growth through trade, and no such stories of growth through selfsufficiency as far as I know.

An important growth mechanism arises when trade raises a country's real income, some of which is saved. The increased saving raises the availability of funds for investment spending, which augments a country's productive capital stock. Developing countries with relatively liberal trade regimes also commonly attract capital from abroad, further augmenting resources devoted to capital formation.

Free trade also increases the possibility that a firm importing a capital good will be able to locate a supplier who will provide a good that more nearly meets its specifications. The better the match, the larger is the increase in the firm's productivity. A 
related idea is that international trade may spur the diffusion of technology by increasing the commercial contacts between employees in firms from different countries.

Another route for economic growth arises due to the increased competitive pressures associated with international trade. By reducing trade barriers, firms that were previously protected are now faced with competitors and, unless they become more efficient and responsive to consumers, they will perish. The result is that productive resources will be used more efficiently in producing goods that consumers desire.

A final route arises because, as trade barriers are reduced, the size of the market that a firm faces increases. In some cases, firms may be able to expand output at lower per-unit costs. The larger market size might also spur increased research and development spending that could spur additional growth.

How does the theory of international trade work in practice? Specifically, does international trade allow a country to achieve a higher real income than it would have otherwise achieved? The short answer is yes, but it is hard to pin down by precisely how much. ${ }^{4}$ For a country as a whole, the gains are bound to be less for a large country such as the United States than for a small country such as Belgium. Clearly, the costs to Belgium of cutting off all trade with those outside its borders would be huge, as would also be true for a state with roughly similar population, such as Ohio.

There is an enormous professional literature on cases in which some protection might be justified or justified for a short period of time. My own judgment is that few of these arguments really stand up to rigorous analysis. I believe that the correct starting point for analysis is always that trade restriction imposes net costs on society. That is, protection produces gains for some and costs for others, but the net of gains and costs is negative.

The professional literature provides estimates of the cost of protecting a variety of industries. It is not uncommon to find estimates indicating that the cost per job saved is more than $\$ 500,000$ or in some cases even as large as $\$ 1$ million.

\section{REASONS FOR PUBLIC OPPOSITION}

If the logic and evidence supporting free trade is so convincing for economists, why is the general

\footnotetext{
4 See Frankel and Romer (1999) and Irwin and Terviö (2000).
}

public reluctant to embrace free trade? I'll develop three themes in attempting to answer this question. The first theme is that many people do not understand the benefits of free trade. I'll call this "Theme LU," where "LU" stands for "lack of understanding." The second theme is that certain industry groups are able to apply their political power to gain protection, usually because those who bear the costs of protection are inadequately represented in the political process. I'll call this "Theme PP," where "PP" stands for "political power." My third theme is that protection can result from a fully reasoned preference to pay the costs to provide protection because the costs are spread across a wide number of people and because those who are protected would be severely impacted by free trade. I'll call this "Theme RP," where "RP" stands for "reasoned preference."

A good place to begin developing these themes is to reflect first on the case for free trade within the United States. One of the great achievements of the U.S. Constitution was to ban trade restrictions, with minor exceptions, across state lines. Since the early days of the United States, trade within the country has been a great source of economic growth. Some of the transitions have been painful for regions losing jobs, and yet public support for free trade within the United States has never been shaken. New England, especially, has seen many of its manufacturing industries move to other parts of the country and outside the United States as well. The movement of the textile industry to the South is the most famous example. To this day, a traveler in New England can see numerous textile mills built in the 19th century still standing, but converted to other uses.

The job losses in New England were painful, and it took many years to restore full employment there. Workers had to retrain, and some found that they could never restore their previous level of income. Yet the nation supported the industrial transformation, and not just because the Constitution demanded it. New jobs appeared in southern mills, lifting many workers out of rural poverty. The situation was one of "us against them" but the us and the them were in the same country, though in different regions. In some cases, government aid softened the blow suffered by newly unemployed workers in New England, but for the most part they and their families bore the costs of the industrial transformation.

Once the transformation was complete, both New England and the South gained from the new patterns of trade within the United States. The regions as a whole gained, but obviously many 
individuals and individual firms in New England did not. Trade does create losers, even though regions as a whole gain.

The gains from international trade are harder to understand than the gains from interregional trade. Within a country, it is easy to see that trade creates jobs in some regions and destroys jobs in other regions. Some of the adjustments from international trade involve job creation abroad and job losses at home. The gains from such trade are much harder to understand. This lack of understandingmy Theme LU - has a lot to do with support for restrictions on international trade.

Let me try to dispel some of the poor understanding of this issue. I'll focus on job gains and losses. On the surface, in any given country it appears that exports add jobs and imports cost jobs when workers in the home country find that they cannot compete with low-cost goods from abroad. So, it appears that a country could add jobs in total by subsidizing exports and blocking imports. Let's follow the logic of just such a policy, and let's assume that no countries abroad retaliate. Let's also assume that the home country is capable of producing all the goods that had been imported, so that blocking all imports does not create any untenable shortages of particular commodities.

Suppose exporters insist on payment in dollars for the goods they sell. How will foreigners obtain dollars once all their exports to the United States are cut off? Will U.S. banks lend the dollars, even though foreign firms have no possibility of selling goods in the United States to obtain dollars to repay loans? The answer is obvious.

Or perhaps U.S. exporters will accept foreign currency in payment for the goods sold abroad. What will they do with the foreign currencies? The currencies cannot be used to buy goods to import into the United States because all imports are blocked. The foreign currencies cannot be sold abroad for dollars because foreigners have no dollars to sell as a consequence of not being able to earn dollars through sale of goods to the United States. Exporters could use the foreign currencies to buy assets abroad, such as land, but presumably at some point they will tire of exchanging all their goods for foreign assets.

This argument makes clear that the heart of the argument against restricting imports is that doing so restricts exports. Every exporting firm and every worker employed by such a firm ought to have an intense interest in maintaining free trade. The connection may seem remote, but it is real: every dollar of blocked imports is also, at least eventually, a dollar of blocked exports. To point out the folly of the view that exports are good and imports bad, a 19th century economist satirically wondered whether the best outcome would be for ships transporting goods between countries to sink so that all countries could have exports without imports.

It is clear that imports and exports are connected in a fundamental way. Nevertheless - and this is a key point - a dollar of blocked imports has concentrated positive effects for the protected industry but diffuse negative effects across all export industries, amounting to pennies per item for any given export industry. In terms of jobs, blocking imports has obvious job benefits for the protected industry, whereas the job losses from reduced exports are spread widely across many industries. Trade restriction produces concentrated benefits and extremely diffuse and hard to understand costs. The costs are borne by export firms and their workers and by consumers who pay higher prices.

This fact, that protection produces concentrated gains and diffuse losses, is the source of Theme PP. Industries suffering from imports have a great incentive to seek redress through the political process, and they are often successful in doing so. Industries suffering a handful of job losses, and consumers paying a few pennies more for the goods they buy, may not even notice the losses. In any event, because the losses are individually small, those bearing the losses have no incentive to organize politically to fight protection. But keep in mind that a job loss here, and two or three there, can add up to many job losses per job saved in a protected industry.

My third theme is that fully informed voters might rationally prefer protection in some cases. Being unemployed, regardless of its length, is a noteworthy cost that generates opposition to proposed trade policy changes from both those likely to be adversely affected and those who empathize with them.

Consider the policy choices available to policymakers who are trying to protect jobs. There are really only three options. One is to swallow hard and do nothing. This option may sound cruel, but the fact is that the government leaves family and markets to handle many types of misfortunes that befall us. A second is to provide adjustment assistance to help workers make the transition from industries suffering intense import competition to new industries.

A third option is to impose import restrictions. 
As I have already emphasized, these restrictions impose costs on the rest of society. A natural question is why individuals, including those with relatively low incomes, should bear the costs of maintaining jobs in other industries. The question is particularly pointed when workers in protected industries are earning wages above the national average.

In some cases, certainly, protection improves the job and income prospects of low-income workers. Many voters do appear willing to support trade restrictions to protect such workers. Protection in these circumstances seems to fit my Theme RPthat voters have a reasoned preference to bear the costs of protecting low-income workers. The willingness, therefore, to support trade restrictions may in some cases simply reflect a concern for others.

This sense of community may extend beyond U.S. borders. Many U.S. consumers appear willing to pay higher prices for items produced under better working conditions in developing countries. Moreover, most Americans favor linking labor standards to trade. For example, the 1999 Program on International Attitudes survey found that 93 percent of respondents felt that as part of international trade agreements countries should be required to maintain minimum standards for working conditions. ${ }^{5}$

However, this linkage may instead reflect self-interest. By effectively raising the cost of its competitors, higher labor standards would serve the interests of those being harmed by the imports from low-cost competitors.

Similar to linking labor standards to trade, some sentiment exists for linking environmental standards to trade. Underlying this sentiment is a belief that by stimulating growth, trade contributes to environmental problems. Some of the concern about the environment can be linked to U.S. jobs. One argument is that lower environmental standards abroad make the U.S. a less-competitive location and induce firms to relocate. Thus, by harmonizing environmental standards, the disadvantages of production in the United States due to environmental controls would be eliminated.

Many economists, however, would argue that environmental problems should be handled nationally and that international differences in environmental standards are natural. Moreover, economic growth provides both the resources and the demand to raise a country's environmental standards. In

\footnotetext{
5 See the University of Maryland, Program on International Policy
} Attitudes (PIPA) fact, the ideal tradeoffs between economic growth and environmental quality that a country might make are likely to depend on its level of economic development. For example, research by economists Gene Grossman and Alan Krueger finds an inverted U-shaped relationship between pollution and economic development. ${ }^{6}$ For very poor countries, increases in per capita gross domestic product are associated with worsening environmental conditions. Beyond some income level, however, increases in per capita gross domestic product are associated with improving environmental conditions; wealthier societies can and do spend more on pollution control. The turning point varies for the specific pollutant, but in almost every case the turning point occurs at a per capita income of $\$ 8,000$ or less in 1985 dollars. Thus, raising the income of poor countries, a direct result of increased international trade, may be the most important factor in improving environmental conditions in low-income countries.

Despite the insights from my second and third themes, I return to Theme LU - that attitudes toward trade are heavily influenced by a lack of understanding. Quite generally, the public fails to see any broadbased gains from trade. For example, the 1999 Program on International Attitudes survey found that Americans viewed the benefits of trade as flowing to business, rather than to themselves or to American workers in general. Although the survey did not ask respondents whether they thought gains from trade went to foreigners, I'm guessing that many Americans do believe that foreigners harvest the gains and the United States loses from trade.

The difficulty of envisioning broad-based gains for the United States is understandable. It is difficult for the general public to perceive that reducing import barriers lowers prices, raises average wages, and improves jobs across a wide range of U.S. industries. It is also difficult for the general public to envision how freer trade will spur economic growth that will improve its well-being. Because U.S. international trade is already largely free, the gains for an average U.S. individual of fostering free trade are small. In other words, the gains from even freer trade as a share of total economic activity in the United States are relatively small; however, the total gains are substantial.

The general public is also concerned about the large and increasing U.S. trade deficit. Some of the concern reflects a view that U.S. exports should equal U.S. imports. This view fails to appreciate

6 See Grossman and Krueger (1995). 
that a country's trade balance and its capital account are very closely related. In a speech November 14 , 2003, at the Tucson chapter of the Association for Investment Management Research, I examined this relationship. I do not have time today to develop the points I made in that speech, so I will summarize some key points.

Via basic accounting, a country's capital account surplus is equal to its current account deficit. For simplicity, let's view the current account deficit as the trade deficit. A common mistake is to treat international capital flows as though they are passively responding to what is happening in the trade account. In fact, investors abroad buy U.S. assets not for the purpose of financing the U.S. trade deficit but because they believe these assets are sound investments, promising a good combination of safety and return. On a personal level, every one here has the option of moving funds abroad, for example, through mutual funds that invest in foreign stocks and bonds. Why is the net capital flow into rather than out of the United States? The reason is that for most investors the United States is the capital market of choice. There is no better place in the world to invest.

In sum, the United States has created for itself a comparative advantage in capital markets, and we should not be surprised that investors all over the world come to buy the product. As investors exploit the opportunities provided by U.S. financial markets, trade deficits can arise. Thus, my view is that our current trade deficits are not a cause for alarm because on the whole they reflect extremely positive forces driving the U.S. capital account.

\section{NARROWING THE GAP}

Now let me turn to the issue of how to narrow the gap between the opinions of economists and the general public. The first response of economists to narrowing the gap involves education. That is the obvious implication of Theme LU. However, the educational challenge is large because the majority of the general public will not be sitting through an international trade course. These communication issues are especially important because economists' arguments are often focused on issues that the general public tends to ignore or, at least, downplay.

Economists often focus on consumption aspects of international trade. They stress that free trade allows for increases in well-being because consumers can buy more and varied goods at lower prices. Public discussions, however, usually focus on jobs and production.
The statement that imports destroy some jobs is certainly correct; however, the key point is that trade causes a change in the distribution of jobs and no major change in the number of jobs, once adjustments to changing trade patterns are complete. The nature of the popular discussion highlights the job destruction aspects of trade and downplays the job creation aspects of trade. It is far easier to identify a closed plant or laid-off factory workers than it is to find the new economic activity, which is often widely dispersed, resulting from a reduction in trade barriers.

It is easy to see why workers losing their jobs would be passionately opposed to international trade. Conversely, the diffuse beneficiaries of free trade may not even realize that their good fortune arises from free trade. To maintain support for free trade policies, therefore, it is important to identify export success stories and to stress the broad-based gains to consumers stemming from lower prices.

In light of the costs imposed on some by trade, an argument can be made that programs should be available to reduce the cost for those harmed. The trade adjustment assistance program, which is administered by the U.S. Department of Labor, allows those who lose their jobs because of increased imports to receive unemployment compensation for an additional period beyond that received by other displaced workers. In addition, trade adjustment assistance recipients can also participate in retraining programs plus receive out-of-area job search allowances and moving expenses.

To the extent that this program is sufficiently funded and successful, it is possible that this program would reduce workers' lobbying efforts against trade liberalization. Even if voters are motivated by their perceptions of collective well being and not simply their own individual well being, trade adjustment assistance might increase support by those who gain and those who lose.

A third way to bridge the gap between supporters and detractors of trade liberalization is to increase the topics involved in trade negotiations. Sentiment is strong for linking labor and environmental issues with trade negotiations. Sentiment also exists for multilateral trade negotiations to deal with investment policy, competition policy, electronic commerce, and better enforcement of intellectual property rights. What is unclear is whether such changes would ultimately increase the prospects for liberalizing trade. Expanding the agenda might provide negotiators with more opportunities for 
compromise; however, expanding the agenda might also bog down negotiations by introducing issues upon which compromise is very difficult.

Negotiations to reduce trade barriers are motivated by the desire to reap the benefits from freer trade. Negotiations - whether they are multilateral, regional, or bilateral-are always contentious. The multilateral agreements underpinning the World Trade Organization attempt to counteract protectionist pressures. As a last resort, the dispute settlement process allows countries to retaliate against a member found in violation of an agreement.

Retaliation provides a mechanism to enforce the treaty. We might also think of targeted retaliation as a way to make highly visible the job losses in export industries when a country imposes import restrictions. As argued earlier, in the absence of targeted retaliation, job losses in export industries are widely scattered and difficult to identify. Targeted retaliation, however, can create visible, concentrated costs on certain export industries - costs that are designed to create political opposition to import restrictions. I might note that nations ratifying the WTO treaty were very familiar with the retaliation rules, as they had been applied for many years under WTO's predecessor organization, the General Agreement on Tariffs and Trade, or the GATT.

\section{CONCLUSION}

I can summarize my perspective on international trade in a few words. Free trade is a policy that increases economic well being for a country as a whole. Specialization and exchange are the routes that generate the benefits. Specialization allows for increased productivity and higher wages, while open markets are more competitive and yield lower prices for consumers.

I've suggested three themes as to why free-trade policy continues to be a matter of controversy: first, that many trade issues are poorly understood; second, the concentrated nature of adverse trade effects combined with the diffuse nature of trade gains creates a political dynamic favoring protection in some cases; and, third, in some cases voters may prefer to pay the costs of protection for the purpose of sheltering vulnerable groups from the full rigors of open international markets.

The challenge for educators, economists, and policymakers is to find ways to increase political support for free trade. It is clear that there is much work left to be done.

\section{REFERENCES}

Alston, Richard M.; Kearl, J.R. and Vaughan, Michael B. "Is There a Consensus Among Economists in the 1990's?" American Economic Review, May 1992, 82(2), pp. 203-9.

Frankel, Jeffrey A. and Romer, David. "Does Trade Cause Growth?” American Economic Review, June 1999, 89(3), pp. 379-99.

Grossman, Gene M. and Krueger, Alan B. "Economic Growth and the Environment." Quarterly Journal of Economics, May 1995, 110(2), pp. 353-77.

Irwin, Douglas and Terviö, Marko. "Does Trade Raise Income? Evidence from the Twentieth Century.” NBER Working Paper 7745, National Bureau of Economic Research, June 2000.

Mayda, Anna Maria and Rodrik, Dani. "Why Are Some People (and Countries) More Protectionist than Others?" NBER Working Paper 8461, National Bureau of Economic Research, September 2001.

Ricardo, David. On The Principles of Political Economy and Taxation. New York: Penguin, 1971.

Reilly, John E., ed. American Public Opinion and U.S. Foreign Policy 1999. Chicago: Chicago Council on Foreign Relations, 1999.

University of Maryland, Program on International Policy Attitudes. Americans on Globalization: A Study of Public Attitudes. College Park, MD: March 2000. 
RE V I E W 